Mongolian Academy of Sciences
Mongolian Journal of Chemistry
Institute of Chemistry \& Chemical Technology

\title{
Specific characteristics of essential oils of four Artemisia species from the Mongolian Trans-Altai Gobi
}

\author{
N.Javzmaa ${ }^{1 *}$, Sh.Altantsetseg ${ }^{1}$, S.Shatar ${ }^{1}$, T.Enkhjargal $^{2}$, Z.Anu ${ }^{3}$ \\ 1 Institute of Chemistry and Chemical Technology, MAS, Peace ave., Ulaanbaatar 13330, Mongolia \\ ${ }^{2}$ Ach Medical University, Peace ave., Ulaanbaatar, Mongolia \\ ${ }^{3}$ Mongolian National University of Medical Sciences, School of Pharmaceutical and Biomedical Sciences, \\ Mongolia
}

ARTICLE INFO: Received 02 November 2015; revised 20 January 2016; accepted 23 January 2016

\begin{abstract}
The essential oil compositions of four Artemisia species in Mongolian Trans-Altai Gobi were studied by gas chromatography (GC) and gas chromatography-mass spectrometry (GC-MS). The oil from A.macrocephala Jacq and A.dracunculus Ledeb. were characterized by the presence of monoterpene hydrocarbons and oxygenated monoterpeneoids predominately. E-nerolidol (26.95\%), methyleugenol (23.29\%) and sabinene (13.21\%) were found as main components in the essential oils of A.dracunculus. A.macrocephalla was characterized by the presence of chamazulene (13.8\%), cineol (11.7\%), myrcene (9.0\%), germacrene-D (7.1\%). A.anethifolia Web was characterized by the presence of fragrant compounds as camphor (26.05\%), $\alpha$-thujone (10.1\%), borneol (5.1\%). Davanone and davanone derivatives were also detected in the sample in amount of $7.7 \%$ in total. A.scoparia Waldst differed by domination of monoterpene hydrocarbons (78.9\%) with (Z)$\beta$-ocimene (29.24\%), $\alpha$-pinene (15.19\%), limonene (10.27\%) and myrcene (9.61\%).
\end{abstract}

Keywords: Wormwood, essential oil composition, chamazulene, 1.8-cineol, camphor,

\section{INTRODUCTION}

The genus of Artemisia (family Asteraceae) which contains many useful aromatic and medicinal plants, comprises of about 400 species found in the northern hemisphere [1]. The genus Artemisia presents 103 species that are found wild all over the Mongolia [2, 3]. Artemisia popularly known as "sagebrush" or "wormwood" is a source of valuable drugs and essential oils. Because of medicinal importance and intricate chemical composition of several varieties and chemotypes, Artemisia continues to be subject of wide interest for chemists and taxonomists.

The genus Artemisia produces a great number of terpenoid compounds in glandular trichomes which have been found to be biologically active [4]. Currently, the pharmaceutical [5-8], food science [9, 10], fragrance $[9,11]$ and in perfumery [12], cosmetical industries [13] are intensively studying the terpenoids of Artemisia and their sesquiterpenoid lactones [14-16].

The Artemisia species are rich in volatile oils that exhibit a wide spectrum of biological activity as antiinflammatory, antibacterial, antifungal, anti-oxidant, antiviral, allelopathic etc $[17,18]$.

A.macrocephala, A.scoparia are used as an antiseptic, anti-inflammatory, antihelmintic, tonic as well as for the treatment of stomachache and toothache in Mongolian traditional medicine $[4,5,8]$.

A literature survey revealed only a few reports on essential oil composition of A.macrocephala, A.scoparia and many researches for A.dracunculus is known Tarragon [19-22].

*corresponding author: email: njavzmaa@gmail.com DOI: http://dx.doi.org/10.5564/mjc.v16i0.667
Tarragon possesses insecticide and radicalscavenging activities. Antifungal, antitumor and DNAdamaging effects were also reported for the essential oil of A.dracunculus [23]. Worthy of mention is the use of the aromatic leaves of A.dracunculus in perfumery and range of food applications which include soups, causes, salad dressing and in the Tarragon vinegar [9, 10, 23, 24].

Previously, reported constituents of A.macrocephala were flavonoids, alkaloids, saponins and terpenes including $\alpha$-pinine, $\beta$-pinine, limonene, $p$-cymene, borneol and 1,8-cineole in the essential oil of the plant. The oil also contains camphor propionic acid, acetic acid, enanthic acid and isovaleric acid. [21, 22, 25]. Mohammad Shoaib et al., examined that the essential oil of A.macrocephala possesses acetylcholinesterase and butyrylcholinesterase inhibitory potential and revealed from the study beneficial applications of the oil in treatment of various neurodegenerative disorders including Alzeimer's disease, Parkinson's disease, ataxia and all other forms of dementia [25].

A.scoparia has medicinal properties like antichlosterolemic, antipyretic, antiseptic, antibacterial, diuretic, cholagogue, vasodilator [19]. The seeds and young flowering stem of the plant, yield an essential oil that also finds extensive use in medicine. Essential oil of this plant has strong antioxidant and insecticidal activity against stored-product insects $[6,20,21]$.

In 1976, Shatar et al., examined the chemical composition of A.scoparia oil produced from plants grown in Mongolian Gobi. The compounds identified in the GC were as follows: $\alpha$-pinene $(15.0 \%)$, camphene $(12.0 \%), \quad \beta$-pinene $(1.2 \%)$, sabinene 
$(6.0 \%), 3-\delta$-carene $(2.4 \%)$, myrcene $(2.5 \%)$, terpinene $(4.3 \%), \alpha$-phellandrene $(3.5 \%), \beta$-phellandrene $(3.0 \%)$, p-cymene $(5.0 \%)$, longicyclene $(2.5 \%)$, longifolene $(0.3 \%), \quad \beta$-bisabolene $(0.6 \%), \quad \beta$-santalene $(0.2 \%)$, $\alpha$-himachalene $(2.5 \%), \gamma$-bisabolene $(0.4 \%), \delta$-cadinene $(1.8 \%)$ and curcumene $(0.2 \%)$ [21]. We reported the chemical composition of the essential oil of Mongolian twenty two Artemisia species previously [24, 26-29].

The essential oil composition of Artemisia anethifolia has not been investigated so far.

As a part of our studies on Artemisia species in Mongolian Trans-Altai Gobi, we have now investigated the essential oil composition of A.dracunculus, A.macrocephala, A.anethifolia and A.scoparia.

\section{EXPERIMENTAL}

Plant material: Aerial parts of A.scoparia, A.anethifolia, A.macrocephala and A.dracunculus were collected from wild growing plants in Mongolian Trans-Altai Gobi at full flowering and fruiting stage in July-September 2011-2013. The exact dates of each harvesting are showed in Table 1.

A voucher specimen has been deposited in the Herbarium fund of the Institute of Botany of the Mongolian Academy of Sciences, Ulaanbaatar, Mongolia.

Isolation of oil: Air-dried aerial parts (70-80 g) were subjected to a hydro distillation in Clevenger type apparatus for $3 \mathrm{~h}$. The samples were yielded $0.43 \%$ (w/w) of $A$.scoparia oil, $0.75 \%$ of $A$.anethifolia oil, $0.23 \%$ of A.macrocephala oil and $0.56 \%$ of $A$.dracunculus oil. The oils were dried over anhydrous calcium chloride and stored in sealed vials at $4^{\circ} \mathrm{C}$ before analysis.

Gas chromatography (GC) and gas chromatography and mass spectrometry (GC/MS): GC analysis was carried out on Hewlett Packard HP 5890II Gas Chromatograph fitted with an fused silica DBWax column $(30 \mathrm{~m} \times 0.25 \mathrm{~mm} \times 0.25 \mu \mathrm{m})$; carrier gas nitrogen, linear velocity $38 \mathrm{ml} / \mathrm{min}$, split ratio $30: 1$. The injector and detector temperature was $250^{\circ} \mathrm{C}$, column temperature was programmed from 80 to $200^{\circ} \mathrm{C}$ at a rate $2^{\circ} \mathrm{C} / \mathrm{min}, 0.5 \mu$ l solutions of essential oil samples in dichloromethane $(1 \%)$ were subjected to the injector. Quantitative data were obtained from an electronic integration of the flame ionization detector (FID) peak area. GC-MS analysis was performed on HP 5971A instrument with MS detector 5890II of the same company which was operated in El mode (70eV). GC-MS fitted with a Supelcowax 10 column $(60 \mathrm{~m} \times 0.25 \mathrm{~mm} \times 0.25 \mu \mathrm{m})$; carrier gas helium, linear velocity $10 \mathrm{ml} / \mathrm{min}$, split ratio $30: 1$. The injector and detector temperature was $250^{\circ} \mathrm{C}$ and $280^{\circ} \mathrm{C}$, column temperature was programmed from 80 to $120^{\circ} \mathrm{C}$ at a rate $3^{\circ} \mathrm{C} / \mathrm{min}$. All $\mathrm{GC}$ condition and capillary column used were as described above but a carrier gas was helium.

Identification of components: The separated components were identified by matching with massspectral library data and by comparison of Kovat's indices with those of authentic components and with published data [30-34].

\section{RESULTS AND DISCUSSION}

The essential oils were isolated from the aerial parts of four Artemisia species at full flowering and fruiting stage were obtained in 3 replications and taken means of the oil yields as shown in Table 1. Additionally the place and time of collection of the plant materials are given in Table 1.

Table 1. Essential oil yields of four Artemisia species

\begin{tabular}{|c|c|c|c|}
\hline Plant name & $\begin{array}{l}\text { Date of } \\
\text { collection }\end{array}$ & $\begin{array}{l}\text { Vegetation } \\
\text { period }\end{array}$ & $\begin{array}{c}\text { Oil } \\
\text { yield, } \\
\% \\
\end{array}$ \\
\hline A.scoparia Waldst & August 2012 & $\begin{array}{l}\text { in full } \\
\text { bloom }\end{array}$ & 0.43 \\
\hline A.anethifolia Web & August 2012 & $\begin{array}{l}\text { In full } \\
\text { bloom }\end{array}$ & 0.75 \\
\hline $\begin{array}{l}\text { A.macrocephala } \\
\text { Jacq }\end{array}$ & $\begin{array}{l}\text { September } \\
2013\end{array}$ & ripe fruits & 0.23 \\
\hline A.dracunculus L & July 2011 & $\begin{array}{l}\text { in full } \\
\text { bloom }\end{array}$ & 0.56 \\
\hline
\end{tabular}

The essential oils were obtained from aerial parts of wild growing A.dracunculus, A.anethifolia, A.macrocephala and $A$. scoparia in Mongolian Trans-Altain Gobi. GC and GC-MS analyses led to detection of 88 constituents accounting $88.30-94.03 \%$ of the oils (Table 2 ). The compounds were identified on the basis of their mass spectral characteristics and retention indices on non polar HP-5MS column.

A.dracunculus essential oil contained 44 compound, accounting $88.30 \%$ of the oil. As it seen in Table 2, the oil was rich oxygenated terpenoids: Monoterpenoids $33.66 \%$ and sesquiterpenoids $28.66 \%$. Methyleugenol (23.29\%), E-nerolidol (26.95\%), sabinene (13.21\%) were dominating in the investigated sample. The different observers revealed from previous studies which are noted to be principle chemotype of methylchavicol (35.7-60.46\%), sabinene $(0.11-46.78 \%)$, ocimene $(0.3-$ $13.54 \%)$, $\gamma$-terpinene (2.43-17.01\%) for essential oil of A.dracunculus from South Sibiria, USA, Russia and Italia [10, 29] while the investigated sample has specific chemotype that including considerable amounts of methyleugenol and aromatic alcohols. It can be shown that the A.dracunculus from Mongolian Trans-Altai Gobi can be used for raw material in the medicines, perfumes, cosmetic and food producing.

The oil of A.anethifolia contained 47 compounds, accounting $88.17 \%$ of the oil (Table 2). The sample differed from the described by domination of monoterpenoids (56.94\%), among which are camphor $(26.05 \%), \alpha-\beta$-thujone (14.35\%). In addition, borneol (5.11\%), hexadien-2.4-1-phenyl (4.51\%), caryophyllene oxide $(2.53 \%)$, germacrene-D $(2.53 \%)$, caryophyllene $(2.07 \%)$, spathulenol (2.17\%) were detected as prominent monoterpenoids. A literature survey showed any reports concerning essential oil composition of A.anehifolia. Also the oil differed from the described above by the presence of davanone type compounds (7.73\%) davanone-1, davanone-2, davanone-3, davanone-4 and davanyl ether. Literature survey showed that they accompanied davana type compounds in essential oils and could be described as 
Table 1. Essential oil yields of four Artemisia species, $\%$

\begin{tabular}{|c|c|c|c|c|}
\hline Compounds & A.dracunculus & A.anethifolia & A.macrocephala & A.scoparia \\
\hline$\alpha$-thujene & - & - & - & 0.14 \\
\hline$\alpha$-pinene & - & 0.61 & 1.4 & 15.19 \\
\hline camphene & - & 2.71 & 1.2 & 0.18 \\
\hline sabinene & 13.21 & 0.24 & 0.6 & 3.85 \\
\hline$\beta$-pinene & 1.10 & 0.31 & 0.4 & 5.55 \\
\hline myrcene & 0.88 & - & 9.0 & 9.61 \\
\hline$\alpha$-phellandrene & - & - & 3.6 & - \\
\hline$\alpha$-terpinene & 0.26 & - & 0.4 & 0.26 \\
\hline p-cymol & 0.58 & 0.19 & 1.4 & - \\
\hline limonene & 1.60 & - & 1.2 & 10.27 \\
\hline (E)- $\beta$-ocimene & 0.80 & - & - & 1.02 \\
\hline (Z)- $\beta$-ocimene & 1.24 & - & - & 29.47 \\
\hline$\gamma$-terpinene & 0.71 & - & 0.7 & - \\
\hline terpinolene & 0.45 & - & 0.5 & - \\
\hline Monoterpene hydrocarbones & 22.55 & 4.06 & 20.4 & 78.94 \\
\hline 1.8-cineol & 1.10 & 1.21 & 11.7 & 2.61 \\
\hline lavandulacton & - & 0.33 & - & - \\
\hline artemisia keton & - & 0.75 & - & - \\
\hline (E)-sabinenehydrate & 0.20 & 0.25 & - & - \\
\hline (Z)-sabinenehydrate & 0.33 & 0.27 & 1.6 & 0.09 \\
\hline linalool & 0.31 & 0.21 & 1.2 & - \\
\hline$\alpha$-thujone & 0.23 & 9.95 & - & - \\
\hline$\beta$-thujone & - & 4.40 & - & 0.07 \\
\hline (E)-p-ment-2-en-1-ol & - & 0.93 & - & - \\
\hline chryzanthenon & - & 0.24 & - & - \\
\hline pinocarveol & - & 0.79 & - & - \\
\hline camphor & - & 26.05 & 1.4 & - \\
\hline (E)-chryzanthenol & - & 0.47 & 0.2 & - \\
\hline borneol & - & 5.11 & 0.9 & 0.45 \\
\hline terpin-4-ol & 4.38 & 0.76 & 0.5 & 0.19 \\
\hline isogeraniol & - & - & 1.2 & - \\
\hline$\alpha$-terpineol & 2.68 & 0.38 & 1.9 & 0.08 \\
\hline gernaylacetate & - & - & - & 0.36 \\
\hline methylchavicol & 0.46 & - & - & - \\
\hline myrtenol & - & 1.06 & - & - \\
\hline (Z)-piperitol & - & 1.25 & - & - \\
\hline (Z)-carveol & - & 0.14 & - & - \\
\hline bornylformat & - & 0,19 & - & - \\
\hline carvon & - & 0,20 & - & - \\
\hline methylsalicilate & - & - & - & - \\
\hline bornylacetate & 0.21 & 1.03 & - & - \\
\hline (Z)-piperitolacetate & 0.59 & - & - & - \\
\hline methyleugenol & 23.39 & - & - & - \\
\hline Monoterpenoids & 33.66 & 56.94 & 20.6 & 1.26 \\
\hline$\alpha$-santalene & - & - & - & 1.12 \\
\hline copaene & - & 0.5 & - & - \\
\hline$\beta$-bourbonene & - & - & 0.5 & - \\
\hline$\beta$-elemene & - & - & 0.7 & - \\
\hline caryophyllene & 1.00 & 2.07 & 2.0 & 1.60 \\
\hline humulene & - & - & 0.2 & 0.12 \\
\hline$\beta$-farnesene & 0.29 & - & 2.0 & 0.45 \\
\hline selina-4,11-dien & - & - & 1.3 & - \\
\hline germacrene-D & 0.29 & 2.53 & 7.1 & - \\
\hline$\beta$-selinene & - & - & 4.0 & + \\
\hline$\gamma$-muurolene & 0.19 & - & - & - \\
\hline bicyclogermacrene & 0.86 & - & 1.0 & 2,27 \\
\hline$(E-E)$ - $\alpha$-farnesene & - & - & - & 0.44 \\
\hline$\gamma$-cadinene & - & - & - & 0.33 \\
\hline$\delta$-cadinene & 0.40 & 0.49 & - & - \\
\hline selin-3,7(11)-dien & - & - & 2.6 & 0.90 \\
\hline Chamazulen & - & - & 13.8 & - \\
\hline Sesquiterpene hydrocarbones & 3.43 & 6.89 & 35.2 & 11.75 \\
\hline
\end{tabular}




\begin{tabular}{|c|c|c|c|c|}
\hline lavandulylisobutanoate & - & - & 1.0 & - \\
\hline lavandulyl-3- methylbutanoate & - & - & 2.2 & - \\
\hline E-nerolidol & 26.95 & - & 0.3 & 1.58 \\
\hline hexadien-2,4,1-phenyl & - & 4.51 & - & - \\
\hline neryl-2-methylbutanoate & - & - & 4.0 & - \\
\hline E,E-a-fernezelin & - & 0.45 & - & - \\
\hline davanyl ether & - & 2.21 & - & - \\
\hline neryl-3-methylbutanoate & - & - & 2.2 & - \\
\hline geranyl-2-mehylbutanoate & - & - & 1.4 & - \\
\hline copaborneol & - & - & 2.2 & - \\
\hline geranyl-3-methylbutanoate & - & - & 0.4 & - \\
\hline davanon-1 & - & 1.47 & - & - \\
\hline davanon-2 & - & 2.19 & - & - \\
\hline davanon-3 & - & 1.10 & - & - \\
\hline spathulenol & 1.39 & - & 0.9 & - \\
\hline caryophyllene oxide & 0.32 & 2.17 & 0.4 & 0.13 \\
\hline epi- $\alpha$-cadinol & - & 2.53 & - & 0.11 \\
\hline davanon-4 & - & 0.76 & - & - \\
\hline$\beta$-bisabolol oxide & - & 0.81 & - & 0.26 \\
\hline$\gamma$-eudesmol & - & - & 0.3 & - \\
\hline bisabolol & - & 2.08 & - & - \\
\hline T-cadinol & - & - & 0.4 & - \\
\hline caryophyll-4-en-13-ol & - & - & 0.5 & - \\
\hline Sesquiterpenoids & 28.66 & 20.28 & 16.2 & 2.08 \\
\hline Total identified compounds & 88.30 & 88.17 & 92.4 & 94.03 \\
\hline
\end{tabular}

biogenetically connected with them or their degradation products $[1,10,17]$.

Further, 32 compounds were identified in the A.scoparia essential oil, representing $94.03 \%$ of the studied oil. (Z)- $\beta$-ocimene (29.47\%), $\alpha$-pinene $(15.19 \%)$ and limonene $(10.27 \%)$ were found to be the main terpenoids in analyzed sample. Myrcene (9.51\%), $\beta$-pinene $(5.55 \%)$, sabinene $(3.85 \%)$ were detected in the relatively low concentrations in the investigated sample. Spathulenol, nerolidol, caryophyllene oxide, $\alpha$-cadinol and epi- $\alpha$-bisabolol were the only five sesquiterpenoids detected in amounts of $2.08 \%$ in total. It should be noted a high percentage of $\beta$-ocimene $(29.47 \%)$ in the oil. This compound has not been detected previously in a plant originated from Khangai region, Mongolia. Instead, $\alpha$-pinene, camphene are reported as principle components in the plant [21]. Comparison of the obtained results with those published so far showed similar essential oil profile which was characterized by high percentage of monoterpene hydrocarbons and aromatic compounds. The observed differences were significant and could be due to the effect of ecological conditions or stage of the plant development [29].

Finally, in A.macrocephalla oil were detected 44 compounds, representing $92.4 \%$ of the oil. The obtained results have considerably enlarged data for A.macrocephala essential oil. So far, monterpenoids were known as main components of the oil with borneol (10.8), cineol $(10.7 \%)$, isoborneol $(8.3 \%)$, camphor $(6.3 \%)$ and chamazulene without any quantitative data [21], camphene, limonene, p-cymol, $\alpha$-thujone [7], caryophyllene, $\beta$-selinene [1], 1.8-cineol, $\gamma$-terpinene, sabinene, limonene [29]. These components were presented in the investigated sample, but the oil was characterized by high contents of chamazulene
(13.8\%), 1.8-cineol (11.7\%). Other prominent compounds were myrcene $(9.0 \%)$ and germacrene (7.1\%). A.macrocephala in Mongolian Trans-Altai Gobi could be more anti-inflammatory activity than others which are growing in different areas of Mongolia because of chamazulene content according to the studies by researchers at Siberian State Medical University showed high anti-inflammatory activities for azulene (derivative product is chamazulene) containing essential oils of wormwood [35].

\section{CONCLUSION}

According to the results, specific chemotypes in the essential oils from A.scoparia, A.dracunculus, A.macrocephala in Mongolian Trans-Altain Gobi are revealed comparing with previous researches of the three Artemisia species are wild growing in different regions of the Mongolia. Furthermore chemical compositions of the essential oil from A.anethifolia in the Gobi were investigated firstly [1, 3, 7, 10], which are dominated by monoterpenoids. Determining components as main from the Artemisia species are methyleugenol in A.dracunculus, aromatic alcohols and ketones in A.anethifolia, chamazulene in A.macrocephala possess high bioactivity properties and the essential oils could be effective supplements for medicine, food, perfumer industries.

\section{REFERENCES}

1. Marco J.A., Barbera O. (1990) Natural products from the genus Artemisia L. In: Atta-ur-Kahman (ed) Studies in Natural Products Chemistry. Elsevier Sci. Publ, Amsterdam, 7, 201-264.

2. Grubov V.I. (1982) Key to the vascular plants. Nauka, Leningrad, 443 (in Russian).

3. Gubanov M.I. (1996) Conspectus of flora Outer 
Mongolia. Valang, Moscow, 36 (in Russian).

4. Duke S.O., Paul R.N., Lee S.M. (1988) Terpenoids from the genus Artemisia as Potential pesticides. In Potential use in agriculture. Proc. American Chemical Society, USA, ed. Biologically active natural products. Washington, ACS, 318-334.

5. Atajanova G.A (2008) Biological activity terpenoids of the essential oil of plants and practical aspect their application. In Terpenoids: Achievement and perspective application in region chemistry, technology industry and medicine. 9-11 April 2008, Karaganda, Kazakhstan, 119-137.

6. Shuvalova O., Amelichenko V.P., Krasnoborov A., et al. (2001) Medicinal wormwood, Nevsky prospect, Sankt-Peterburg, 118 (in Russian).

7. Berezovskaya T.P. (1991) Wormwood from Siberia. Nauka, Novosibirsk, 124 (in Russian).

8. Khaidav Ts., Altanchimeg B., Varlamova T.S. (1985) Medicinal plants from Mongolian traditional medicine. National publisher company, Ulaanbaatar, 390 (In Russian).

9. Lavrenova G.V. (1999) Spice and aromatic plants. Stalker, Donetsk, 118-120 (in Russian).

10. Shatar S., Altantsetseg Sh. (2011) Chemical composition and technological characteristics of the essential oils of Artemisia species from Mongolian territory. Ekimto, Ulaanbaatar, 225 (in Mongolian).

11. Peshkova G.I., Shreter A.I (2001) Useful plants in domestic cosmetics and dermatology. Dom MSP, Moscow, 475, 685 (in Russian).

12. Adekenov S.M. (2008) Sesquiterpene lactons of plants spreading in Nature, especially structure molecule and perspective their application. In Terpenoids: Achievement and perspective application in region chemistry, technology industry and medicine. 9-11 April 2008, Karaganda. Kazakhstan, 39-62.

13. Adekenov S.M., Kagarlitskii A.D. (1990) Chemistry sesquiterpene lactons. Gylym, Alma-ata, 188 (in Russian).

14. Rybalko K.S. (1978) Natural sesquiterpene lactons. Medicina. Moscow, 267-268 (in Russian).

15. Tan R.X., Zheng W.F., Tang H.Q (1998) Biologically active substances from the genus Artemisia. $J$. Planta Med., 64(4), 294-302.

16. Bakkali F., Averbesk S., Averbeck D., et al. (2008) Biological effects on essential oils. J. Food. Chem. Toxicol., 46, 446-475.

17. Lawrence B.M. (1990) Wormwood oil. In Progress in Essential Oil. J. Perfumer and Flavorist, 15, 6364.

18. Markov L.P. (1985) Wild growing useful plants of Mongolia, Nauka, Leningrad, 25-34 (in Russian).

19. Konovalvo D., Chelombit K.V. (1991) Composition of essential oil of Artemisia scoparia Waldst et Kit during grow. J. Rastit. Resursy, 27(1), 135-139 (in Russian).

20. Goryaev M.I., Serkebaeva I.S. (1981) The essential oil of Artemisia scoparia Waldst. J. Chem. Nat.
Compound, 5, 560-561 (in Russian).

21. Goryaev M.I., Shatar S. (1976) The essential oil of three Artemisia species from Mongolia. J. Proceeding of the Mongolian academy of science, 3, 40-46. (in Mongolian)

22. Sefidkon F., Jalili A. (2003) Chemical composition of the essential oil of five Artemisia species from Iran. J. Essent. Oil Bearing Plants., 6(1), 41-45.

23. Mohammad Sayah, Leila Nadjafnia, Mohammad Kamalinejab (2004) Aniconvulsant activity and chemical composition of Artemisia dracunculus L. essential oil. Journal of Ethnopharmacology, 94, 283-287.

24. Shatar S. (2011) Chemistry of terpenoids-III: $A$ study of the chemical composition of essential oil of plants from Mongolia. Ekimto, Ulaanbaatar, 8889 (in Mongolian).

25. Mohammad Shoaib. (2015) In vitro acetylcholinesterase and butyrylcholinesterase inhibitory potentials of essential oil of Artemisia macrocephala. Bangladesh J. Pharmacol., 10, 8791.

26. Shatar S., Altantsetseg Sh. (1999) The essential oil composition of six Artemisia species from Mongolia. J. Essent. Oil Bearing Plants, 2(2), 56-67.

27. Shatar S., Dung N.X. (2000) New chemotype of Artemisia dracunculus L. from Mongolia. J. Essent. Oil Res., 3(3), 99-100.

28. Shatar S., Karasawa D. (2003) The essential oil composition of Mongolian some Artemisia species. J. Essent. Oil Bearing Plants, 6(3), 203-207.

29. Shatar S., Altantsetseg Sh. (2006) Chemotypical character of the essential oils of eleven Artemisia species from Mongolian Desert-Gobi. J. Essent. Oil Bearing Plants, 9(1), 22-29.

30. Adams R.P. (1991) Cedar wood-analysis and properties. In: Linskins H.F and Jackson J.F. (eds). Modern methods of Plant analysis: Oils and Waxes. Springer-Verlag, Berlin, 159-173.

31. Adams R.P. (2001) Identification of essential oils components by gas chromatography/mass spectroscopy. Allured Publ, Corp. Carol Stream Illinois, USA.

32. Davies N.W. (1990) Gas chromatographic retention indices of monoterpenes and sesquiterpenes on methyl silicone and Carbowax 20M phases. J.Chromatogr., 503, 1-24.

33. Jounlain D., Konig W.A. (1998) The atlas of spectral data of sesquiterpene hydrocarbons. E.B Verlag, Hamburg, Germany.

34. Tkachev A.V. (2008) Atlas mass spectra: Investigation volatile substance from plant. Ofset, Novosibirsk, 230-781 (in Russian).

35. Sizova N.V. (2012) Composition and antioxidant activity of essential oils containing azulene derivatives. J. Pharmaceutical Chemistry, 46 (6), Russia, 42. 